Article

\title{
Incorporation of Manure into Ridge and Furrow Planting System Boosts Yields of Maize by Optimizing Soil Moisture and Improving Photosynthesis
}

\author{
Anzhen Qin ${ }^{1,+} \oplus$, Yanjie Fang ${ }^{2,3,+}$, Dongfeng Ning ${ }^{1, *}$, Zhandong Liu ${ }^{1}$, Ben Zhao ${ }^{1}$, Junfu Xiao ${ }^{1}$, \\ Aiwang Duan ${ }^{1}$ and Beibei Yong ${ }^{3}$ \\ 1 Key Laboratory of Crop Water Use and Regulation, Ministry of Agriculture and Rural Affairs, Institute of \\ Farmland Irrigation, Chinese Academy of Agricultural Sciences, Xinxiang 453002, China; \\ qinanzhen@126.com (A.Q.); liuzhandong@caas.cn (Z.L.); zhaoben@caas.cn (B.Z.); \\ xiaojunfu1961@163.com (J.X.); duanaiwang@aliyun.com (A.D.) \\ 2 Dryland Agriculture Institute, Gansu Academy of Agricultural Sciences, Lanzhou 730070, China; \\ fangyj82@126.com \\ 3 National Agro-Ecological System Observation and Research Station of Shangqiu, Institute of Farmland \\ Irrigation, Chinese Academy of Agricultural Sciences, Xinxiang 453002, China; yongbeibei@caas.cn \\ * Correspondence: smile_0808@163.com; Tel.: +86-373-3393321 \\ + These authors contributed equally to this work.
}

Received: 23 October 2019; Accepted: 6 December 2019; Published: 10 December 2019

\begin{abstract}
A sustainable management strategy of soil fertility and cropping system is critical to guaranteeing food security. However, little is known about the effects of soil amendment strategies on crop growth via regulating soil moisture and photosynthesis in a ridge and furrow cropping system. Here, field experiments were carried out in 2017 and 2018 in semi-arid areas of Loess Plateau, northwest China to investigate the effects of integrated use of ridge and furrow planting and manure amendment on grain yields of maize. Four treatments were designed: CK (flat planting with 100\% chemical fertilizer), RFC (ridge and furrow planting with 100\% chemical fertilizer), RFR (ridge and furrow planting with $100 \%$ control-released fertilizer), and RFM (ridge and furrow planting with $50 \%$ manure fertilizer $+50 \% \mathrm{~N}$ fertilizer). On average, RFM increased photosynthetic rates (Pn) by $74 \%$, followed by RFR by $47 \%$, and RFC by $26 \%$, compared to CK. Also, stomatal conductance (Cd), transpiration rates $(\mathrm{Tr})$, and intercellular $\mathrm{CO}_{2}$ concentration (Ci) were highest with RFM, followed by RFR and RFC. Averaged across the two years, RFM conserved 10\% more soil water storage (SWS) than CK did at harvest, followed by RFR with an increment by $8 \%$. However, RFC consumed more soil water than $\mathrm{CK}$ did, with its $\mathrm{ET}_{\mathrm{C}} 8 \%$ higher than $\mathrm{CK}$. Consequently, spring maize treated with RFM suffered less drought stress, especially in 2017 when precipitation was insufficient. On average, grain yields and water use efficiency of RFM were increased by $18 \%$ and $27 \%$, compared to CK. Structural equation modeling analysis showed that there existed significant positive correlation between SWS in top layers and grain yields, while SWS in deep layers had negative effects on grain yields. In conclusion, the incorporation of manure into ridge and furrow planting system can be an efficient agronomic practice to improve plant photosynthesis, optimize soil moisture, and boost grain yields in semi-arid areas of Loess Plateau, northwest China.
\end{abstract}

Keywords: structural equation model; organic fertilizer; dry matter; rain-fed agriculture; Zea mays L. 


\section{Introduction}

Rain-fed agriculture is a major cropping system worldwide. Currently, around $60 \%$ of the global grain harvest comes from rain-fed land. However, water scarcity has been a main threat to the agricultural production in rain-fed areas due to limited and erratic precipitation [1]. In most rain-fed areas, the rate of yield gain has been stagnating for years due to the uneven distribution of precipitation, extremities of air temperature, and the excessive depletion of soil water in deep layers. In China, the Loess Plateau is the largest rain-fed areas, whose agricultural production heavily depends on seasonal precipitation. Due to a monsoon climate, $68 \%$ of rainfall occurs between June and September [2]. The annual mean precipitation is $415 \mathrm{~mm}, 48 \%$ less than the annual evapotranspiration (ET, $800 \mathrm{~mm}$ ) in the areas. Furthermore, more than $50 \%$ events take place in the form of low rainfall $(<6 \mathrm{~mm})$, which is hard for maize crops to utilize [3]. This makes it difficult for the precipitation to meet a full yield potential of maize plants. Therefore, it is necessary to adopt some innovative and effective agronomic practices to make good use of low rainfall.

In recent years, many attempts have been made to alleviate water stress to plants and improve rainwater use efficiency [4-6]. Alternatively, ridge and furrow planting with full film mulching (RFP) has been regarded as an effective approach to reduce soil evaporation, harvest rainwater, and conserve soil moisture. The adoption of RFP has been shown to increase crop yields, compared with traditional flat planting. However, RFP usually requires an increased use of chemical fertilizers and pesticides to guarantee yield formation [3]. Also, there is clear evidence that RFP depletes more soil moisture and consumes more nutrients in deep layers than do other planting patterns (e.g., flat planting; furrow planting between ridges) [7]. To meet the higher demand of nutritional uptake by plants with RFP, local farmers generally apply a high dose of compound fertilizers during spring maize life cycle. Consequently, RFP not only accelerates soil desiccation, but also brings about environmental pollution such as high risk of nitrogen leaching and soil degradation [8].

Over the past few years, great efforts have been made to replace or minimize the use of mineral fertilizer via applying animal manure (e.g., swine, sheep, cattle) $[9,10]$. This method is regarded as a feasible approach to keep the rate of grain gain with zero growth of chemical fertilizers consumption. Also, manure amendment has the potential to boost yields through improving soil structure, and enhancing the capacity of water retention [11]. For example, on a degraded tropical Alfisol in south western Nigeria, it was reported that pure poultry manure application at $5 \mathrm{t} \mathrm{ha}^{-1}$ significantly increased maize yield by $60 \%$ and soil organic matter by $45 \%$, compared with the application of $\mathrm{N}$ fertilizers at $100 \mathrm{~kg} \mathrm{ha}^{-1}$ [12]. However, most studies showed that yields were lower with pure manure application as compared with mineral fertilizers because of lower availability of nitrogen in organic [13]. It has been confirmed that manure fertilization should be supplemented with small doses of chemical fertilizers to sustain or improve crop yields [11]. Previous studies reported that using compost at $10 \mathrm{tha}^{-1}$ to replace $50 \%$ of inorganic $\mathrm{N}$ achieved maximum grain yield $\left(6.96 \mathrm{t} \mathrm{ha}^{-1}\right)$ of rice in a slit loam soil in India [14]. In the North China Plain, application of $30 \mathrm{~m}^{3} \mathrm{ha}^{-1}$ swine manure and $20 \mathrm{~kg} \mathrm{ha}^{-1}$ biofertilizers to winter wheat can save more than $50 \%$ of NPK (Nitrogen-Phosphorus-Potassium) fertilizers without scarifying grain yields [15]. In a semi-arid area of northeastern Ethiopia, application of farmyard manure along with $50 \%$ reduction in NPK fertilizers increased grain yield of sorghum by $25 \%$, compared to $100 \%$ of the fertilizer rates [16]. Some studies attributed the yield boosting effects of the combination of manure with chemical fertilizers to a fairly high population of Azotobacter, which favors N-fixing in soils [17]. In contrast, pure chemical fertilizers caused a sharp reduction in microbial biomass in soils, negatively affecting the yields of maize [9].

Photosynthesis is a process that assimilates $\mathrm{CO}_{2}$ and converts it in organic matter. It is an important source of dry matter production, which is highly correlated to yield formation [18]. Variations in photosynthetic parameters are also related to fertilizer types and its application rates. Previous studies showed that the application of $100 \%$ NPK triggered earlier onset of leaf senescence because of the decline of post-anthesis photosynthesis [19]. However, NPK fertilizers incorporated into poultry 
manure was shown to increase photosynthetic activity [20]. Therefore, optimum fertilizer management with high photosynthates may guarantee good crop productivity.

Nevertheless, it is still unclear whether animal manure incorporated into ridge and furrow planting system maximizes these positive effects on increasing water availability, improving crop photosynthetic rates, and boosting yields in semi-arid rain-fed areas. Previous studies have focused on the influence of individual management strategy, as compared to conventional planting and fertilizing practices, but little work has been done comparing the effects these different strategies have. The aim of this study was to comparatively analyze the effects of multiple management strategies on soil water storage (SWS), photosynthetic rates, and grain yields of maize.

In this study, we hypothesized that the development of innovative soil management (manure amendment) and agronomic practice (ridge and furrow planting) optimized soil water storage (SWS), increased leaf photosynthesis, and boosted yields of maize, and that SWS at different layers would make significant contributions to yields of maize. Furthermore, a structural equation modeling (SEM) method was used to investigate the contribution rates of each parameter (e.g., photosynthetic factors and SWS) to grain yields of maize. The SEM method has become an essential statistical approach in social sciences, and it has been a reliable way to identify key factors impacting yields [21]. In recent years, scientists have applied SEM to environmental and ecological research, since SEM can provide a more quantitative and conceptual understanding of the relationships among key variables when modeling phenomena such as complex biogeochemical processes [22].

The objectives of the study were: (i) To validate the yield boosting effects of the integrated use of manure amendment and ridge and furrow planting system and (ii) to estimate what contribution rates of photosynthetic parameters and SWS to grain yields using an SEM method.

\section{Materials and Methods}

\subsection{Site Description}

The field experiments were carried out from 2017 to 2018 at the Dingxi Experimental Station $\left(104^{\circ} 36^{\prime} \mathrm{E}, 35^{\circ} 35^{\prime} \mathrm{N} ; 1970 \mathrm{~m}\right.$ a.s.l.) of Gansu Academy of Agricultural Sciences. The climate belongs to continental monsoon climate, with a long-term (1998-2018) mean annual precipitation of $415 \mathrm{~mm}$, with about $68 \%$ received between May and September. Long-term mean annual temperature is $6.2{ }^{\circ} \mathrm{C}$, and annual sunshine hours are $2477 \mathrm{~h}$. The station is located in the central parts of Loess Plateau, northwest China (Figure 1). The soil is a light loam of loess origin belonging to lithological soil, with sandy loam texture [23]. Soil bulk density, field holding capacity, wilting point, organic matter content, total $\mathrm{N}$, total $\mathrm{P}$, and available $\mathrm{K}$ measured prior to the experiment are presented in Table 1.

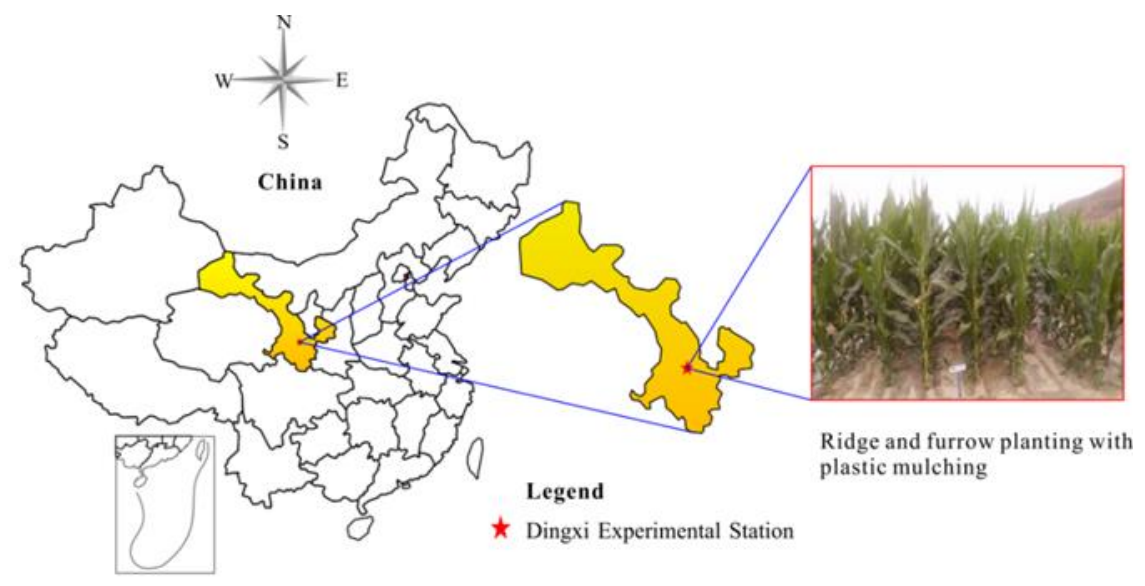

Figure 1. Schematic location of the Dingxi Experimental Station and the ridge and furrow planting with plastic mulching at the Station. 
Table 1. Soil physical properties prior to the start of the experiment at the Dingxi Experimental Station, Loess Plateau, northwest China, in 2017.

\begin{tabular}{|c|c|c|c|c|c|c|c|}
\hline $\begin{array}{l}\text { Soil } \\
\text { Depth }\end{array}$ & $\begin{array}{c}\text { Bulk } \\
\text { Density }\end{array}$ & $\begin{array}{l}\text { Wilting } \\
\text { Point }\end{array}$ & $\begin{array}{l}\text { Holding } \\
\text { Capacity }\end{array}$ & $\begin{array}{c}\text { Organic } \\
\text { Matter } \\
\text { Content }\end{array}$ & $\begin{array}{c}\text { Total } \\
\text { Nitrogen }\end{array}$ & $\begin{array}{c}\text { Total } \\
\text { Phosphorus }\end{array}$ & $\begin{array}{l}\text { Available } \\
\text { Potassium }\end{array}$ \\
\hline $\mathrm{cm}$ & $\mathrm{g} \mathrm{cm}^{-3}$ & \multicolumn{2}{|c|}{$\mathrm{cm}^{3} \mathrm{~cm}^{-3}$} & & $\mathrm{~g} \mathrm{~kg}^{-1}$ & & $\mathrm{mg} \mathrm{kg}^{-1}$ \\
\hline $0-20$ & 1.18 & 8.64 & 22.9 & 11.9 & 1.16 & 1.26 & 378.5 \\
\hline $20-40$ & 1.22 & 8.85 & 23.3 & 11.7 & 1.19 & 1.34 & 358.6 \\
\hline $40-60$ & 1.14 & 9.40 & 23.5 & 11.4 & 1.06 & 1.27 & 278.4 \\
\hline $60-80$ & 1.06 & 9.30 & 23.5 & 10.9 & 1.03 & 1.18 & 196.3 \\
\hline 80-100 & 1.16 & 9.60 & 23.7 & 11.2 & 1.12 & 1.21 & 152.4 \\
\hline $100-120$ & 1.13 & 9.65 & 23.7 & 10.7 & 1.13 & 1.12 & 115.7 \\
\hline $120-140$ & 1.15 & 9.70 & 23.8 & 10.9 & 1.08 & 1.03 & 116.9 \\
\hline $140-160$ & 1.18 & 9.60 & 23.7 & 10.7 & 1.02 & 0.89 & 113.2 \\
\hline $160-180$ & 1.15 & 9.90 & 23.9 & 10.1 & 0.99 & 0.85 & 110.2 \\
\hline 180-200 & 1.16 & 10.0 & 23.9 & 10.2 & 0.83 & 0.79 & 111.3 \\
\hline
\end{tabular}

\subsection{Experimental Treatments and Design}

Three fertilization treatments were carried out with ridge and furrow planting: (1) RFC (ridge and furrow planting with 100\% chemical NPK); (2) RFR (ridge and furrow planting with 100\% control-released fertilizer); and (3) RFM (ridge and furrow planting with $50 \%$ sheep manure and $50 \%$ chemical N), in comparison with (4) CK (a traditional flat planting with 100\% chemical NPK, which was broadly adopted by local farmers) (Table 2). The chemical fertilizers used were urea, calcium superphosphate, and potassium chloride. The control-released fertilizer, produced by Shandong Kingenta Ecological Engineering Group Company, Linyi, China, was composed of a compound fertilizer core and a polymer sulfur-coating agent outside the core, with a longevity of 5 months in spring maize growing seasons [24]. The sheep manure was used to replace $50 \%$ of chemical $\mathrm{N}$ fertilizers. Properties of sheep manure at the experiment station were analyzed before application, and are presented in Table 3. The amounts of control-released fertilizer and sheep manure to be applied were determined according to the percentage composition of $\mathrm{N}_{1} \mathrm{P}_{2} \mathrm{O}_{5}$, and $\mathrm{K}_{2} \mathrm{O}$ to keep the same levels of NPK contents as chemical fertilizers had. Because chemical $\mathrm{N}$ fertilizer released $\mathrm{N}$ faster than the others, $60 \%$ of the total urea was applied as base fertilizers prior to sowing, whereas the remaining $40 \%$ was top-dressed at VT stage. Otherwise, the other types of fertilizers were all applied as base fertilizers.

Table 2. Percentage composition of $\mathrm{N}, \mathrm{P}_{2} \mathrm{O}_{5}$, and $\mathrm{K}_{2} \mathrm{O}$ for different fertilizer types and the application rates were controlled at a similar NPK (Nitrogen-Phosphorus-Potassium) level among treatments.

\begin{tabular}{|c|c|c|c|c|c|c|}
\hline \multirow{2}{*}{\multicolumn{2}{|c|}{ Fertilizer Types }} & \multirow{3}{*}{$\begin{array}{c}\begin{array}{c}\text { Percentage } \\
\text { Composition (\%) }\end{array} \\
\text { N: } 46\end{array}$} & \multirow{3}{*}{$\begin{array}{c}\begin{array}{c}\text { Application } \\
\text { Rates (kg ha-1) }\end{array} \\
490\end{array}$} & \multicolumn{3}{|c|}{ Equivalent NPK Rates $\left(\mathrm{kg} \mathrm{ha}^{-1}\right)$} \\
\hline & & & & \multirow{2}{*}{$\begin{array}{c}\mathbf{N} \\
225\end{array}$} & \multirow{2}{*}{$\frac{\mathrm{P}_{2} \mathrm{O}_{5}}{-}$} & \multirow{2}{*}{$\frac{\mathrm{K}_{2} \mathbf{O}}{-}$} \\
\hline \multirow{3}{*}{$\begin{array}{l}\text { Chemical } \\
\text { fertilizer }\end{array}$} & Urea & & & & & \\
\hline & $\begin{array}{c}\text { Calcium } \\
\text { superphosphate }\end{array}$ & $\mathrm{P}_{2} \mathrm{O}_{5}: 16$ & 560 & - & 90 & - \\
\hline & Potassium chloride & $\mathrm{K}_{2} \mathrm{O}: 60$ & 120 & - & - & 72 \\
\hline \multicolumn{2}{|c|}{ Control-released fertilizer } & $\begin{array}{c}\mathrm{N}-\mathrm{P}_{2} \mathrm{O}_{5}-\mathrm{K}_{2} \mathrm{O}: \\
25-10-8\end{array}$ & 900 & 216 & 90 & 72 \\
\hline \multirow{2}{*}{$\begin{array}{l}\text { Manure } \\
\text { fertilizer }\end{array}$} & Sheep manure & $\begin{array}{l}\mathrm{N}-\mathrm{P}_{2} \mathrm{O}_{5}-\mathrm{K}_{2} \mathrm{O}: \\
1.85-1.50-1.25\end{array}$ & 6000 & 110 & 90 & 74 \\
\hline & $50 \%$ urea & $\mathrm{N}: 46$ & 245 & 112 & - & - \\
\hline
\end{tabular}


Table 3. Properties of sheep manure used in the experiment.

\begin{tabular}{|c|c|c|c|c|c|c|}
\hline Property & $\mathrm{pH}$ & 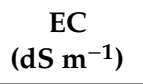 & $\begin{array}{l}\text { Moisture } \\
\text { Content (\%) }\end{array}$ & $\begin{array}{l}\text { Orgainc C } \\
\left(\mathrm{g} \mathrm{kg}^{-1}\right)\end{array}$ & $\begin{array}{c}\text { Water Soluble } \\
\text { Organic C }\left(\mathrm{g} \mathrm{kg}^{-1}\right)\end{array}$ & $\begin{array}{l}\text { Total N } \\
\left(\mathrm{g} \mathrm{kg}^{-1}\right)\end{array}$ \\
\hline Manure & 8.1 & 4.87 & 58.6 & 204.2 & 13.7 & 18.5 \\
\hline Property & $\begin{array}{l}\text { Available N } \\
\left(\mathrm{mg} \mathrm{kg}^{-1}\right)\end{array}$ & $\begin{array}{c}\text { Total P } \\
\left(\mathrm{g} \mathrm{kg}^{-1}\right)\end{array}$ & $\begin{array}{l}\text { Available P } \\
\left(\mathrm{mg} \mathrm{kg}^{-1}\right)\end{array}$ & $\begin{array}{c}\text { Total K } \\
\left(\mathrm{g} \mathrm{kg}^{-1}\right)\end{array}$ & $\begin{array}{l}\text { Available K } \\
\left(\mathrm{mg} \mathrm{kg}^{-1}\right)\end{array}$ & $\begin{array}{l}\text { Decomposition } \\
\text { Rate }(\%)\end{array}$ \\
\hline Manure & 74.1 & 15.2 & 152.4 & 12.1 & 128.6 & 68.3 \\
\hline
\end{tabular}

Note: decomposition rate in a year was measured using in situ nylon mesh bags burying method.

Absorbing ratio of NPK for the cultivar Xianyu 335 in Dingxi was approximately 2.14:0.53:1.56 [3]. When average grain yield of $9500 \mathrm{~kg} \mathrm{ha}^{-1}$ was estimated, the needs of NPK for Xianyu 335 during a life cycle were around $203 \mathrm{~kg} \mathrm{~N} \mathrm{ha}^{-1}, 52 \mathrm{~kg} \mathrm{P}_{2} \mathrm{O}_{5} \mathrm{ha}^{-1}$, and $148 \mathrm{~kg} \mathrm{~K}_{2} \mathrm{O} \mathrm{ha}^{-1}$. Because the soils in Dingxi are rich in available $\mathrm{K}$, but lack available $\mathrm{P}$, actual application rate of $\mathrm{K}$ was reduced by about $50 \%$ while that of $\mathrm{P}$ was increased by $45 \%$. All treatments were mulched with full plastic film. Ridge and furrow planting consisted of a wide ridge $(70 \mathrm{~cm}$ in width and $10 \mathrm{~cm}$ in height) and a narrow ridge $(40 \mathrm{~cm}$ in width and $20 \mathrm{~cm}$ in height) (Figure 2). Maize seeds (cv. Xianyu 335) were sown in the furrows between the alternating wide and narrow ridges with an average row spacing of $55 \mathrm{~cm}$ and a plant-to-plant spacing of $30 \mathrm{~cm}$, giving a planting density of $6 \times 10^{4}$ plants ha $^{-1}$. Plot size was $39.9 \mathrm{~m}^{2}(5.7 \mathrm{~m} \times 7.0 \mathrm{~m})$ with three replications, for a total of 12 plots in a randomized block design. The planting density, row distance, plant-to-plant spacing, and plot size were the same in the two consecutive experimental years, as well as the field management. Fertilizers and sheep manure were applied to the surface incorporated to $20 \mathrm{~cm}$ depth. The preceding crop was spring maize in the experimental field for the past decade. As a rain-fed cropping system, no irrigation was applied to maize plants. Maize was sown on 20 April in both years and harvested on 5 October in 2017 and 8 October in 2018, and aboveground crop residues were all removed in both years According to field observations, maize plants entered V6 in mid-June, tasseling (VT) in late July, R3 in mid-August, and maturity in late September. Weeds and pests control was applied according to the local governmental recommendations.
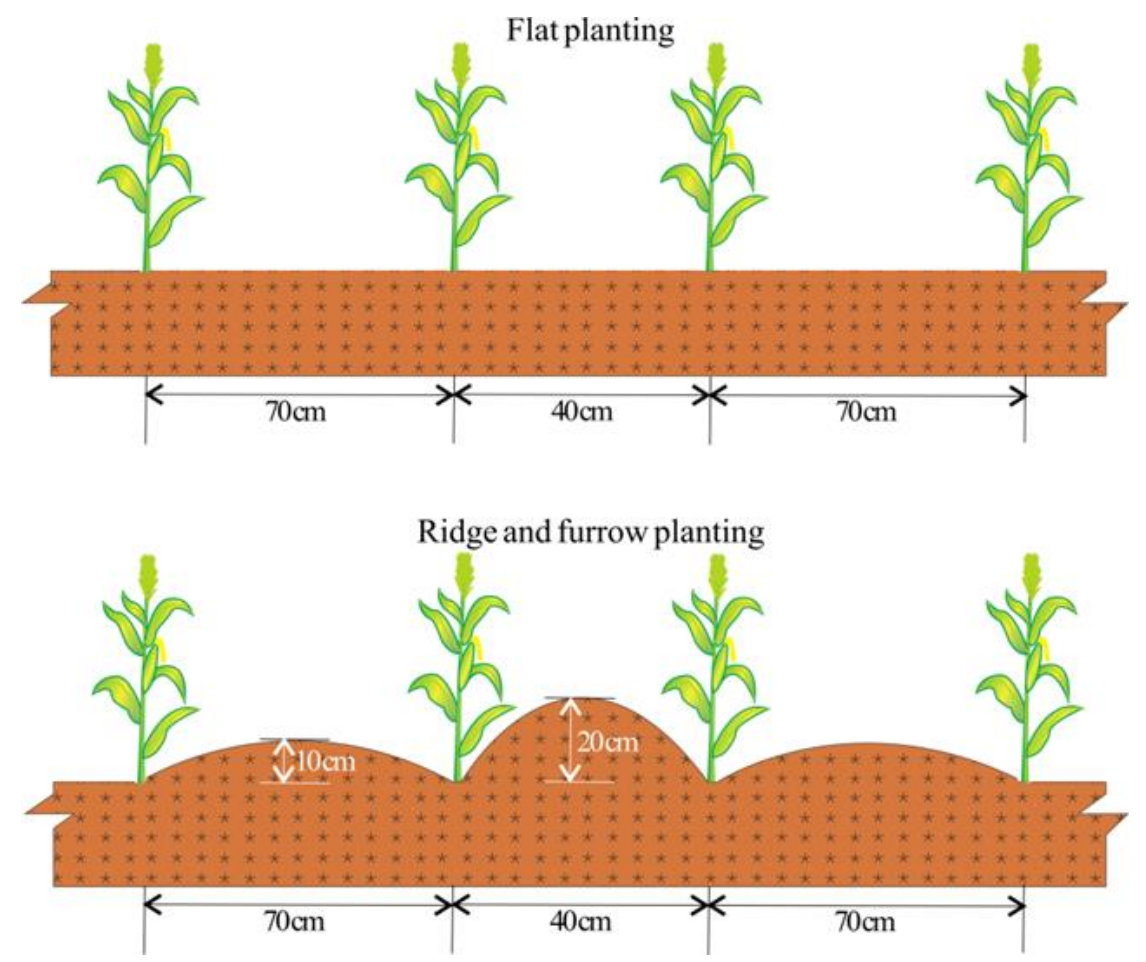

Figure 2. Planting patterns of flat planting and ridge and furrow planting with plastic mulching at the Dingxi Experimental Station. 


\subsection{Data Collection and Measurements}

\subsubsection{Precipitation and Air Temperature}

Precipitation and air temperature were recorded hourly through an automatic meteorological station at Dingxi Experimental Station of Gansu Academy of Agricultural Sciences.

\subsubsection{Soil Water Storage}

Soil gravimetric water content $(\%, w / w)$ was measured at $20 \mathrm{~cm}$ increments to a depth of $200 \mathrm{~cm}$ using a 5-cm diameter corer. Three soil cores were randomly sampled each time from furrows in each plot. They were then oven-dried at $105^{\circ} \mathrm{C}$ for $8 \mathrm{~h}$ after the fresh weight weighed, and then were measured on a dry weight basis. Soil bulk density $\left(\mathrm{g} \mathrm{cm}^{-3}\right)$ at the same depth and intervals was determined after harvest using stainless steel ring method. The volumetric water content $\left(\mathrm{cm}^{3} \mathrm{~cm}^{-3}\right.$, $v / v)$ was calculated by multiplying the soil water content (\%) with soil bulk density from the same layer. Soil water storage (SWS, $\mathrm{mm}$ ) was a product of volumetric water content $\left(\mathrm{cm}^{3} \mathrm{~cm}^{-3}\right)$ by each thickness of soil layer to a depth of $200 \mathrm{~cm}$.

\subsubsection{Dry Matter Accumulation and Grain Yield}

The aboveground dry matter (DM) was measured at the V3, V6, V12, VT, R2, and R6 stages of maize. Ten uniform individual plants before $\mathrm{V} 6$, and five plants hereafter were randomly sampled from each plot, and then were separated into grain, stems, leaves, sheathes, and cobs. The plant samples were oven dried at $105^{\circ} \mathrm{C}$ for $30 \mathrm{~min}$ to cease biological enzyme activity and then were oven-dried at $80^{\circ} \mathrm{C}$ for at least $72 \mathrm{~h}$ to reach a constant weight. The DM weight of each component was measured using an electronic balance, and then was totaled as a sum of dry mass of the abovementioned components.

The seasonal dynamics of $D M$ accumulation can be described using a logistic function, which was expressed as follows:

$$
D M=\frac{A}{1+B \cdot \exp (-K t)}
$$

where $D M$ is dry matter weight $\left(\mathrm{g}_{\text {plant }}{ }^{-1}\right), A$ is the maximal value of $D M\left(\mathrm{~g} \mathrm{plant}^{-1}\right), B$ and $K$ are function parameters to be fitted $(B>0, K>0)$, and $t$ is days after sowing $(d)$.

To determine the grain yield, ears were randomly hand-harvested from 50 maize plants in each plot. They were then air dried for at least 3 weeks until constant mass, and then the grain was separated, cleaned, and weighed. Grain yield was calculated on a dry-matter basis $(13 \%, w / w)$.

\subsubsection{Relevant Photosynthetic Parameters}

Relevant photosynthetic parameters, including photosynthetic assimilation rate (Pn, $\left.\mu \mathrm{mol} \mathrm{CO} \mathrm{Cm}_{2} \mathrm{~m}^{-1}\right)$, transpiration rate $\left(\mathrm{Tr}, \mathrm{mmol} \mathrm{H}_{2} \mathrm{O} \mathrm{m} \mathrm{m}^{-2} \mathrm{~s}^{-1}\right)$, stomatal conductance $(\mathrm{Cd}$, mol $\left.\mathrm{H}_{2} \mathrm{O} \mathrm{m}^{-2} \mathrm{~s}^{-1}\right)$, and intercellular $\mathrm{CO}_{2}$ concentration $\left(\mathrm{Ci}, \mu \mathrm{mol} \mathrm{CO} \mathrm{Col}^{-1}\right.$ air), were measured from 09:00 to 11:00 at the VT and R3 stages on the ear leaves of three uniform plants from three selected sampling areas in each plot using a Li-6400XT Portable Photosynthesis System (Li-Cor Inc., Lincoln, $\mathrm{NE}$, USA). The chamber was adjusted to $25^{\circ} \mathrm{C}$ (temperature), $360 \mu \mathrm{M} / \mathrm{mol}\left(\mathrm{CO}_{2}\right)$, and $800 \mu \mathrm{M} \mathrm{m}^{-2} \mathrm{~s}^{-1}$ (photosynthetic photon-flux density).

\subsubsection{Evapotranspiration and Water Use Efficiency}

Total evapotranspiration (ET, $\mathrm{mm}$ ) during maize growing season was estimated using the SWS at sowing minus SWS at harvest plus the growing season precipitation. Because the annual precipitation is around $400 \mathrm{~mm}$, and the annual ET reaches to $800 \mathrm{~mm}$ at the experimental station, deep percolation was ignored. Because plot surface was flat and each plot was separated by ridges, surface runoff was assumed to be negligible. Water use efficiency (WUE, $\mathrm{kg} \mathrm{ha}^{-1} \mathrm{~mm}^{-1}$ ) was calculated as the grain yield $\left(\mathrm{kg} \mathrm{ha}^{-1}\right)$ produced per unit of ET (mm). 


\subsubsection{Structural Equation Model}

Structural equation model (SEM) is a multivariate statistic procedure to estimate the correlation coefficients of each path in a system of variables. SEM is always used to investigate the complex networks of relationships among variables. All data of SWS, DM, grain yields, and photosynthetic parameters were measured variables in SEM analysis. Latent variable of photosynthesis was reflected by the measured variables of $\mathrm{Pn}, \mathrm{Cd}, \mathrm{Ci}$, and Tr. Latent variables of WaterTop and WaterDeep were reflected by the SWS data in the depth of $0-60 \mathrm{~cm}$ and $60-200 \mathrm{~cm}$, respectively.

\subsection{Statistical Analysis}

All data were subjected to analysis of variance (ANOVA) using SPSS version 24.0 (IBM Corp., Armonk, NY, USA), and differences between the means were tested by least significant difference (Duncan multiple comparison method, $p<0.05$ ). Principal component analysis was implemented. The SEM software AMOS 9.0 was adopted to evaluate the influencing paths for different relationships developed through our hypotheses. Compared with regression methods, the SEM approach permits the integration of errors in models, providing an explicit choice for structural analysis. To assess the goodness of fit of the final model, we performed four additional tests: The adjusted goodness of fit index (AGFI), the comparative fit index (CFI), the normed fit index (NFI), and the root-mean-square error of the approximation (RMSEA). Low RMSEA and high AGFI, CFI, and NFI represent a good fit.

\section{Results}

\subsection{Rainfall and Air Temperature at the Experimental Site}

Based on the analysis of rainfall data in past years (2014-2018), the 2017 season was considered as relatively normal (324 mm), whereas the 2018 season considered wet $(425 \mathrm{~mm}$ ) (Figure 3). Precipitation distributed evenly in 2017, with no events higher than $23 \mathrm{~mm}$. Precipitation in 2018 season was 31\% higher, in which $46 \%$ (196 mm) of the precipitation occurred during V6 to VT, and 35\% (148 mm) during VT to R6. The average air temperature during spring maize season was 15.5 and $15.6^{\circ} \mathrm{C}$ in 2017 and 2018, respectively. The highest air temperature occurred on 20 July $\left(25.1^{\circ} \mathrm{C}\right)$ and 28 July $\left(21.9^{\circ} \mathrm{C}\right)$, in 2017 and 2018, respectively. The lowest air temperature was recorded on 21 April $\left(5.1^{\circ} \mathrm{C}\right)$ and 7 October $\left(5.9^{\circ} \mathrm{C}\right)$ in 2017 and 2018 , respectively.

\subsection{Photosynthetic Parameters}

Photosynthetic parameters were measured on ear leaves at VT and R3 stages, including photosynthetic assimilation (Pn), transpiration rate (Tr), stomatal conductance (Gs), and intercellular $\mathrm{CO}_{2}$ concentration (Ci) of spring maize in 2017 and 2018 (Figure 4). Ridge and furrow planting with $50 \%$ manure fertilizer $+50 \% \mathrm{~N}$ fertilizer (RFM) significantly increased Pn by $66 \%$ (2017) and $71 \%$ (2018) at VT stage, and 54\% (2017) and 105\% (2018) at R3 stage, compared to flat planting with 100\% chemical fertilizer (CK). Averaged across the two years, ridge and furrow planting with $100 \%$ chemical fertilizer (RFC) and ridge and furrow planting with $100 \%$ control-released fertilizer (RFR) increased Pn by $31 \%$ and $35 \%$ at VT stage, and $21 \%$ and $58 \%$ at R3 stage, compared to CK. Tr treated by RFM was the highest at VT stage in both years, but the value declined significantly at R3 stage for all treatments, indicating a descending trend in plant transpiration. On average, RFM increased $\operatorname{Tr}$ by $49 \%$ (2017) and 67\% (2018), compared to CK. However, there were no significant differences in Tr among RFC, RFR, and CK at VT stage in 2017 and at R3 stage in 2018. RFM showed significant positive effects on $\mathrm{Cd}$ and Ci. On average, RFM increased Cd by 65\% (2017) and 106\% (2018), compared to CK. As for intercellular $\mathrm{CO}_{2}$ concentration (Ci), an increase of $44 \%$ (2017) and $58 \%$ (2018) was observed under RFM treatment, compared to CK. The effect of RFC and RFR on Cd varied across precipitation years. In a normal year (2017), RFC had greater positive effects on Cd than RFR did, whereas in a wet year (2018), RFR showed greater effects on Cd at R3 stages, which might be attributable to the promotion of release of nutrient elements in control-released fertilizers in the wet year. As for $\mathrm{Ci}$, there existed no 
significant differences between RFC and RFR in both years, but they were significantly higher than that of CK, with an increase of $14 \%$ at VT stage and $28 \%$ at R3 stage in both years.
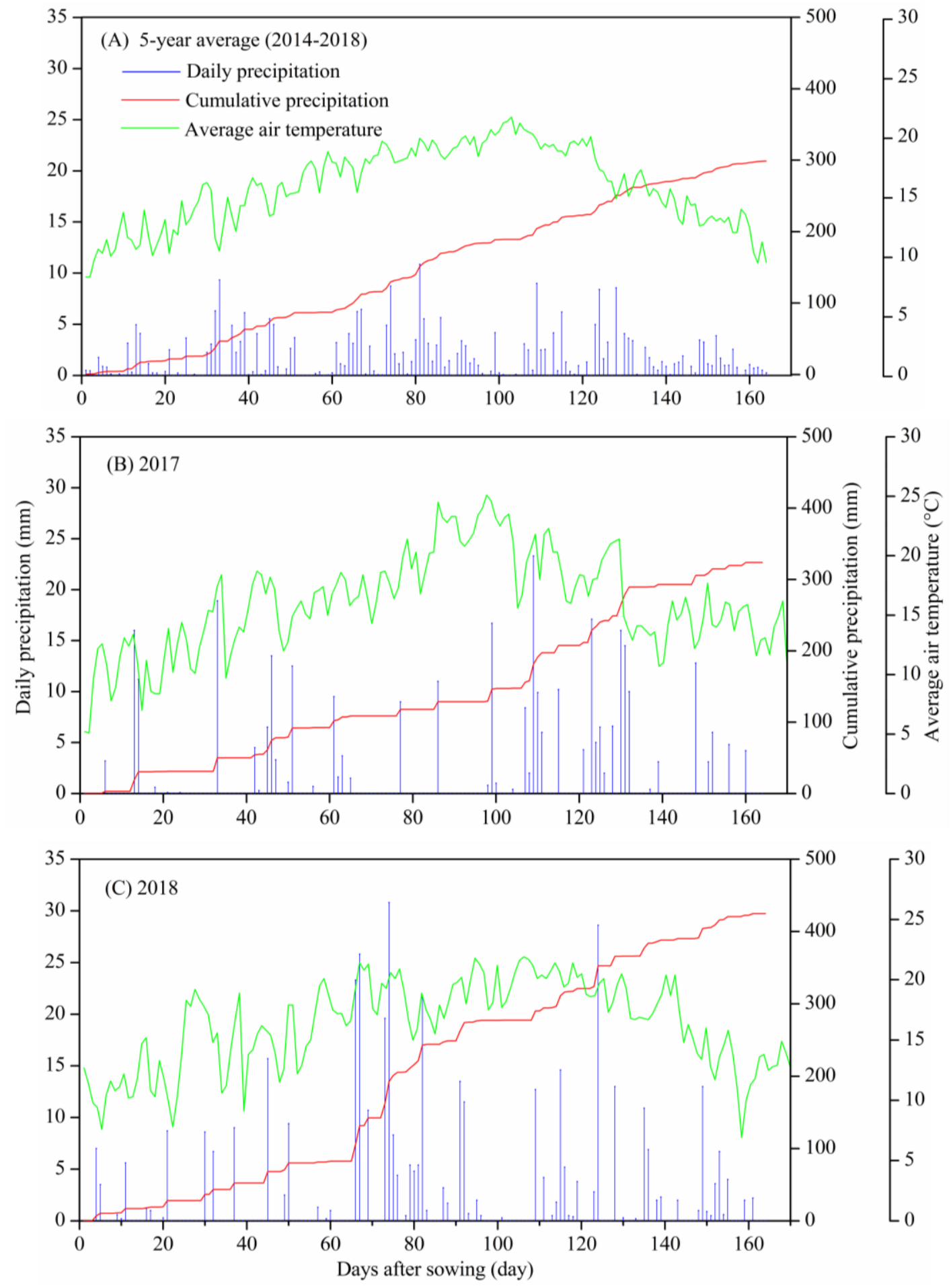

Figure 3. Daily and cumulative precipitation $(\mathrm{mm})$, and daily average air temperature $\left({ }^{\circ} \mathrm{C}\right)$ from April to September at Dingxi Experimental Station. (A) Five-year average values during 2014-2018; (B) data in 2017 and (C) data in 2018. 

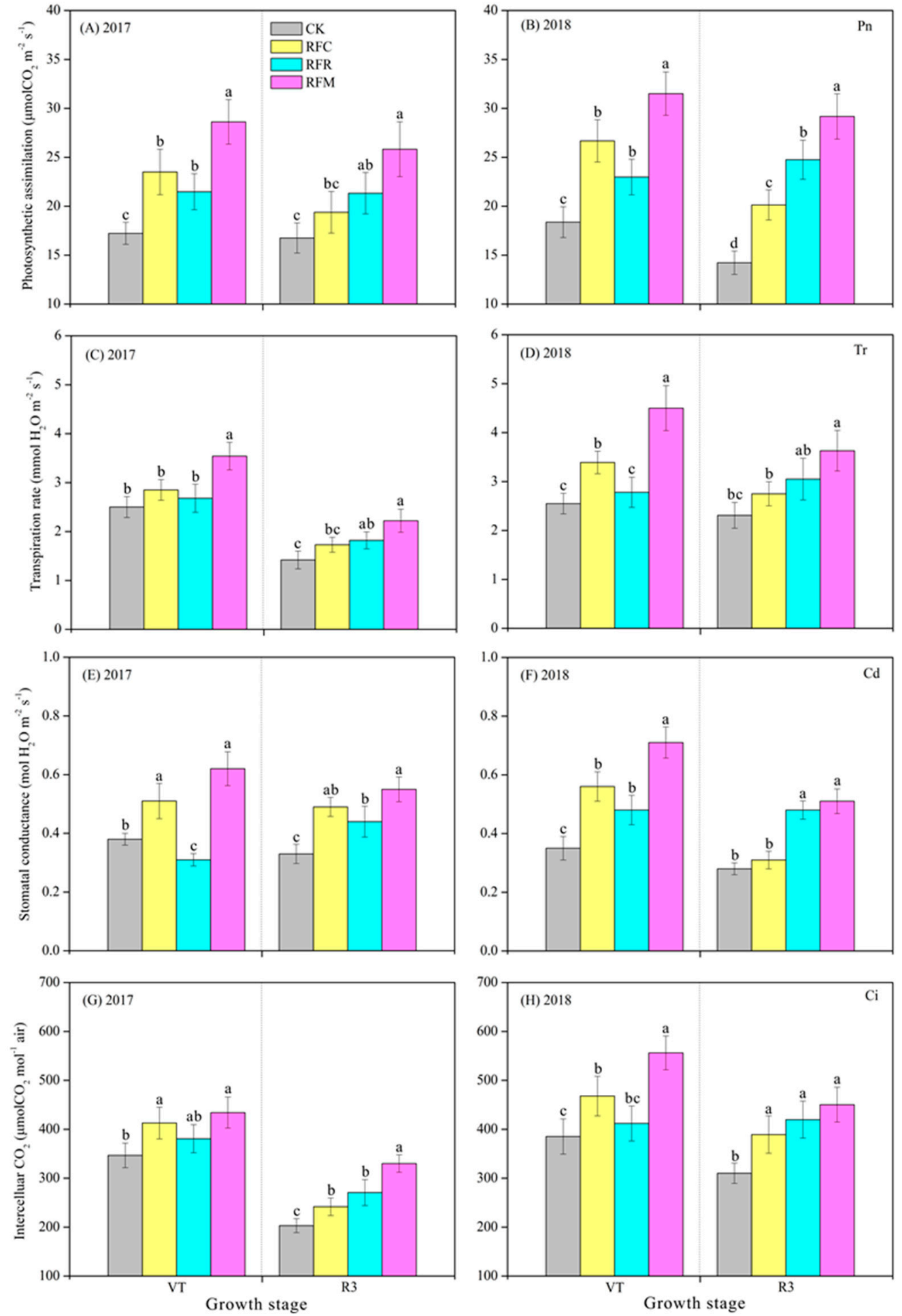

Figure 4. Photosynthetic assimilation (A,B), transpiration rate (C,D), stomatal conductance (E,F), and intercellular $\mathrm{CO}_{2}$ concentration $(\mathrm{G}, \mathrm{H})$ at VT and R3 stages of spring maize at Dingxi Experimental Station in 2017 and 2018. Different letters at VT or R3 stages in each Figure represent significant differences at $p<0.05$.

\subsection{Dry Matter Accumulation}

Seasonal dynamics of maize dry matter (DM) were fit to the logistic function in both years (Table 4). RFM gave rise to the highest maximum $\mathrm{DM}\left(\mathrm{DM}_{\max }\right)$, followed by RFR and RFC, and the minimum was CK. Differences in $\mathrm{DM}_{\max }$ between RFR and RFC was not significant in either years. In 2017, 
maize plants treated by RFM reached the maximum growth rate of $6.80 \mathrm{~g} \mathrm{plant}^{-1}$ day $^{-1}$ at 96 DAS, 4-6 days earlier than the other treatments; while in the wet year of 2018, the maximum growth rate of RFM was $6.59 \mathrm{~g} \mathrm{plant}^{-1} \mathrm{day}^{-1}$ at DAS 99. Compared to 2017, RFR generated higher maximum DM accumulation rate in 2018 when precipitation distribution coincided with the water needs of maize plants. However, the date when maximum accumulation rate occurred fell on the same day in 2018 among RFM, RFR, and RFC, with the maximum accumulation rates followed by RFM $>$ RFR $>$ RFC.

Table 4. Logistic function obtained on the basis of three replicates of day matter weights at different growth stages. The function describes the relationship between dry matter (DM: $\left.\mathrm{g} \mathrm{plant}^{-1}\right)$ and days after sowing (DAS: day) as $\mathrm{DM}=\mathrm{A} /(1+\mathrm{B} \times \exp (-\mathrm{K} \times \mathrm{DAS}))$.

\begin{tabular}{|c|c|c|c|c|c|c|}
\hline Treatments & $\mathrm{DM}_{\max }$ & B & $\mathbf{K}$ & $\mathrm{V}_{\max }$ & DAS $_{\max }$ & $\mathrm{R}^{2}$ \\
\hline & g plant ${ }^{-1}$ & & & $\begin{array}{c}\text { g plant }^{-1} \\
\text { day }^{-1}\end{array}$ & day & \\
\hline \multicolumn{7}{|l|}{2017} \\
\hline CK & $339 c$ & 546 & 0.062 & $5.26 \mathrm{c}$ & $102 \mathrm{a}$ & $0.996^{* *}$ \\
\hline RFC & $382 \mathrm{~b}$ & 403 & 0.059 & $5.64 \mathrm{~b}$ & $102 \mathrm{a}$ & $0.994^{* *}$ \\
\hline RFR & $382 b$ & 497 & 0.062 & $5.92 \mathrm{~b}$ & $100 \mathrm{ab}$ & $0.995^{* *}$ \\
\hline RFM & $406 \mathrm{a}$ & 637 & 0.067 & $6.80 \mathrm{a}$ & $96 \mathrm{~b}$ & $0.992 * *$ \\
\hline \multicolumn{7}{|l|}{2018} \\
\hline CK & $352 c$ & 375 & 0.058 & $5.11 \mathrm{c}$ & $102 \mathrm{a}$ & $0.996^{* *}$ \\
\hline RFC & $379 b, c$ & 424 & 0.061 & $5.78 \mathrm{~b}$ & $99 \mathrm{~b}$ & $0.994^{* *}$ \\
\hline RFR & $399 \mathrm{~b}$ & 555 & 0.064 & $6.39 \mathrm{a}$ & $99 \mathrm{~b}$ & $0.995^{* *}$ \\
\hline RFM & $440 \mathrm{a}$ & 378 & 0.060 & $6.59 \mathrm{a}$ & $99 \mathrm{~b}$ & $0.992^{* * *}$ \\
\hline
\end{tabular}

Note: $\mathrm{DM}_{\max }$ is the maximum dry matter weight $\left(\mathrm{g} \mathrm{plant}^{-1}\right) ; \mathrm{B}$ and $\mathrm{K}$ are function parameters to be fitted $(B>0$, $K>0) ; V_{\max }$ represents the maximum dry matter accumulation rate $\left(\mathrm{g} \mathrm{plant}^{-1}\right.$ day $\left.^{-1}\right) ; \mathrm{DAS}_{\max }$ is days after sowing when $\mathrm{V}_{\max }$ appears (day); $R^{2}$ is coefficients of determination. Different letters within a column and experimental year stand for significant differences at $p<0.05$, and ${ }^{* *}$ means significance at $p<0.01$.

\subsection{Soil Moisture Dynamics}

Soil water storage (SWS) at major stages of spring maize varied greatly across different precipitation years (Figure 5). In the normal year of 2017, SWS under all treatments was close to wilting point in 0-120 cm soil layers at VT stage, in 40-200 cm layer at R3 stage, and in 120-200 cm at R3 stage, indicating maize plants suffered from drought stress at major growth stages. There was only one precipitation event with $11 \mathrm{~mm}$ falling from V8 to VT (DAS 65-95) in 2017. During this one-month duration of drought, SWS was very low at topsoil. Nevertheless, SWS was greatest with RFM, intermediate with RFR, and least with RFC and CK. By adding up, SWS in 0-200 cm layer treated by RFM was $225 \mathrm{~mm}$ at VT stage in 2017, or 7\%, 18\%, and 17\% higher than that of RFR, RFC, and CK, respectively. Although cumulative precipitation was $194 \mathrm{~mm}$ from VT to R6 (DAS 95-170), SWS in 0-60 cm at R3 stage, and SWS in 0-100 cm at R6 stage was still close to wilting point, showing maize plants were subjected to drought stress in middle or deep layers in 2017. On average, total SWS in 0-200 cm layer was greatest with RFM (247 mm), intermediate with RFR $(231 \mathrm{~mm})$, and least with RFC (219 mm) and CK (216 mm) at R3 and R6 stages of 2017. In contrast to circumstances in 2017, abundant precipitation well relieved maize plants of drought suffering in 2018. Precipitation distributed relatively evenly during V6 to VT (196 mm), and VT to R6 (148 mm) in 2018, which favored soil moisture conditions in the 0-200 cm layer. Greater precipitation even made SWS of RFM very close to water-holding capacity in 40-140 cm layer at VT stage. Furthermore, precipitation during VT to R6 period also created favorable soil moisture conditions for maize plants. SWS in 0-200 cm layer treated by RFM was significantly higher than that of CK, and was greatest among all treatments at VT and R6 stages of 2018. However, RFM conserved very similar SWS in 0-200 cm layer to RFR (346 mm vs. $341 \mathrm{~mm}$ ) at R3 stage of 2018, indicating RFR provided similar SWS as RFM did. 

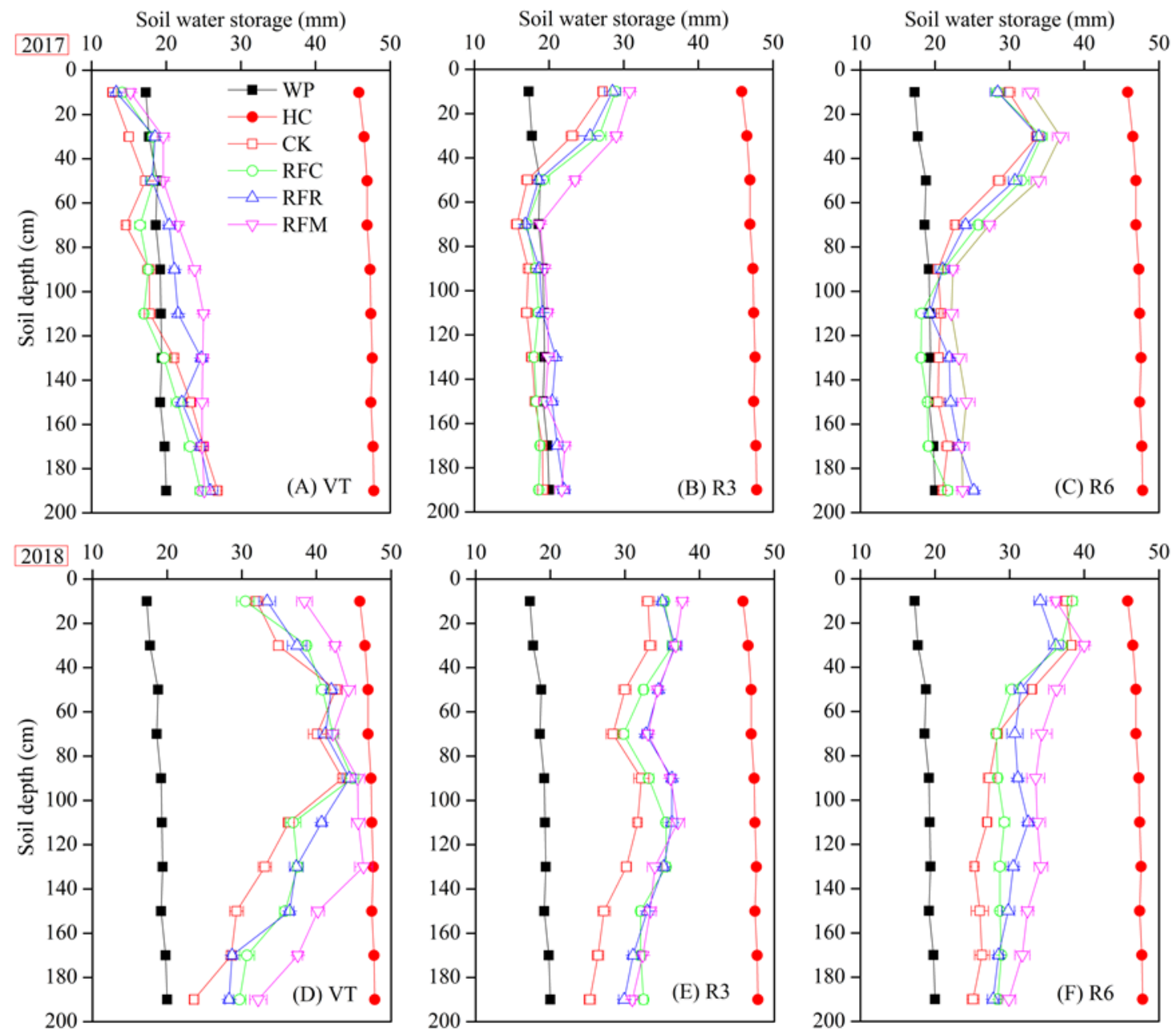

Figure 5. Dynamics of soil water storage in 0-200 $\mathrm{cm}$ soil depth at VT (A,D), R3 (B,E), and R6 (C,F) stages of spring maize at Dingxi Experimental Station in 2017 and 2018. Solid dark squares stand for soil water storage at wilting point, and solid red cycles represent soil water storage at field holding capacity. Bars are standard errors at $p<0.05$.

\subsection{Yield, Evapotranspiration, and Water Use Efficiency}

Ridge and furrow planting with manure amendment (RFM) had significant yield advantage over the other treatments (Table 5). Grain yields with RFM were 9242 and 11,102 kg ha ${ }^{-1}$ in 2017 and 2018, or increased by $19 \%$ and $16 \%$, respectively, compared to CK. RFC resulted in the highest $\mathrm{ET}_{\mathrm{C}}$ of maize in both years due to its lowest SWS after maize harvest. On average, RFM reduced $\mathrm{ET}_{\mathrm{c}}$ by $8 \%$ in both years, while RFC increased $\mathrm{ET}_{\mathrm{c}}$ by $8 \%$, compared to $\mathrm{CK}$. Consequently, RFM gave rise to the highest WUE in both years, with an increase by $27 \%$, compared to CK. It is worth noting that grain yields in 2018 were much greater than those in 2017, due to an evenly distributed and adequate precipitation in 2018. Similar trends were also observed in the case of $\mathrm{ET}_{\mathrm{C}}$ and WUE. Averaged across all treatments, grain yields, $\mathrm{ET}_{\mathrm{c}}$, and WUE in 2018 were $24 \%, 15 \%$, and $7 \%$ higher than those in 2017, respectively. 
Table 5. Seasonal precipitation, soil water storage, crop evapotranspiration, grain yield, and water use efficiency under different fertilization and planting treatments at Dingxi Experimental Station in 2017 and 2018.

\begin{tabular}{|c|c|c|c|c|c|c|}
\hline \multirow{2}{*}{ Year/Treatments } & \multirow{2}{*}{ Pre (mm) } & \multicolumn{2}{|c|}{ SWS (mm) } & \multirow{2}{*}{$\mathrm{ET}_{\mathrm{c}}(\mathrm{mm})$} & \multirow{2}{*}{$\begin{array}{c}\text { GY } \\
\left(\mathrm{kg} \mathrm{ha}^{-1}\right)\end{array}$} & \multirow{2}{*}{$\begin{array}{c}\text { WUE } \\
\left(\mathrm{kg} \mathrm{ha}^{-1} \mathrm{~mm}^{-1}\right.\end{array}$} \\
\hline & & $\begin{array}{l}\text { Before } \\
\text { Sowing }\end{array}$ & $\begin{array}{c}\text { After } \\
\text { Harvest }\end{array}$ & & & \\
\hline \multicolumn{7}{|l|}{2017} \\
\hline CK & 324 & $272 \mathrm{~b}$ & $283 \mathrm{~b}$ & $313 b, c$ & $7797 \mathrm{~b}$ & $24.9 \mathrm{~b}$ \\
\hline RFC & 324 & $284 \mathrm{a}$ & $256 \mathrm{c}$ & $352 a$ & $7949 \mathrm{~b}$ & $22.6 \mathrm{c}$ \\
\hline RFR & 324 & $279 a b$ & $279 \mathrm{~b}$ & $324 \mathrm{~b}$ & $7698 \mathrm{~b}$ & $23.8 \mathrm{bc}$ \\
\hline RFM & 324 & $271 \mathrm{~b}$ & $297 a$ & $298 \mathrm{c}$ & 9242 a & $31.0 \mathrm{a}$ \\
\hline \multicolumn{7}{|l|}{2018} \\
\hline CK & 425 & $270 \mathrm{~b}$ & $310 \mathrm{c}$ & $385 \mathrm{~b}$ & 9593 c & $24.9 c$ \\
\hline RFC & 425 & $286 \mathrm{a}$ & $312 c$ & $399 a$ & 9929 b & $24.9 c$ \\
\hline RFR & 425 & $292 \mathrm{a}$ & $364 \mathrm{a}$ & $353 c$ & $9756 b, c$ & $27.6 \mathrm{~b}$ \\
\hline RFM & 425 & $269 \mathrm{~b}$ & $351 \mathrm{~b}$ & $343 c$ & $11,102 \mathrm{a}$ & $32.4 \mathrm{a}$ \\
\hline
\end{tabular}

Note: Pre, precipitation; SWS, soil water storage; $\mathrm{ET}_{\mathfrak{c}}$, crop evapotranspiration; GY, grain yield; WUE, water use efficiency. Values are the means of three replicates, and different letters within a column and experimental year stand for significant differences at $p<0.05$.

\subsection{Model Development}

A structural equation model (SEM) was developed to compare the effects of SWS and photosynthetic parameters (Pn, Cd, Ci, and $\mathrm{Tr}$ ) on dry matter accumulation, and grain yields during both years (Figure 6). To construct a generalized conceptual SEM model, dimensionality of a set of data should be reduced using principal components analysis (PCA) [25]. Principal component scores were given by the orthogonal projection of the data onto eigenvectors. The eigenvalues were always in descending order, where the first component or eigenvalue had the largest variance (44.9\%), and the second eigenvalue had the second largest (28.5\%), and so on (Table S1). Consequently, three principal components were considered as subsets of data accounting for a substantial proportion of the variance (93.7\% in this study) (Table S2). The model proved reliable with all fit indices (CFI, NFI, and IFI) larger than 0.85 , which confirmed a well performed SEM model in the study. The path model and the standardized path coefficients were significant at $p<0.05$. It was worth noting that DM and grain yield had a positive linear relationship with SWS in top layers but was negatively related to SWS in deep layers. Standardized path coefficient between DM and deep-layer SWS was -0.87 (Table 6). In contrast, photosynthetic parameters and SWS in top layers positively impacted DM accumulation, and thus grain yields. The path coefficient from photosynthesis to DM accumulation was lower than that of top-layer SWS (0.30 vs. 0.67$)$, indicating that photosynthetic parameters were a less important limiting factor than top-layer SWS. The negative path coefficient (-0.87) from deep-layer SWS to DM probably indicated that higher SWS in 60-200 cm induced by abundant seasonal precipitation (e.g., $425 \mathrm{~mm}$ in 2018) might not be conducive to better yield formation. Obviously, the effect of top-layer SWS on DM and yield of maize was the dominant factor to yield formation.

Table 6. Correlation coefficients $\left({ }^{*}\right.$ and ${ }^{* *}$ means significance at $p<0.05$ and $\left.p<0.01\right)$ among latent variables and their contributions to dry matter weights and grain yields of maize.

\begin{tabular}{|c|c|c|c|c|c|c|c|}
\hline \multirow{2}{*}{$\begin{array}{c}\text { Latent } \\
\text { Variables }\end{array}$} & \multicolumn{3}{|c|}{ Correlation Coefficients } & \multirow{2}{*}{$\begin{array}{l}\text { Direct Effects } \\
\text { on DM }\end{array}$} & \multirow{2}{*}{$\begin{array}{l}\text { Indirect Effects } \\
\text { on Yield }\end{array}$} & \multirow{2}{*}{\multicolumn{2}{|c|}{$\begin{array}{l}\text { Contribution Contribution } \\
\text { to DM to Yields }\end{array}$}} \\
\hline & Photosynthesis & WaterTop & WaterDeep & & & & \\
\hline Photosynthesis & 1 & $0.54 *$ & $0.76^{* *}$ & $0.30 *$ & $0.26 *$ & 0.09 & 0.07 \\
\hline WaterTop & - & 1 & $0.81 * *$ & $0.67^{* *}$ & $0.57 *$ & $0.45^{*}$ & $0.32 *$ \\
\hline WaterDeep & - & - & 1 & $-0.87^{* *}$ & $-0.74 * *$ & $0.76^{* *}$ & $0.55^{*}$ \\
\hline
\end{tabular}




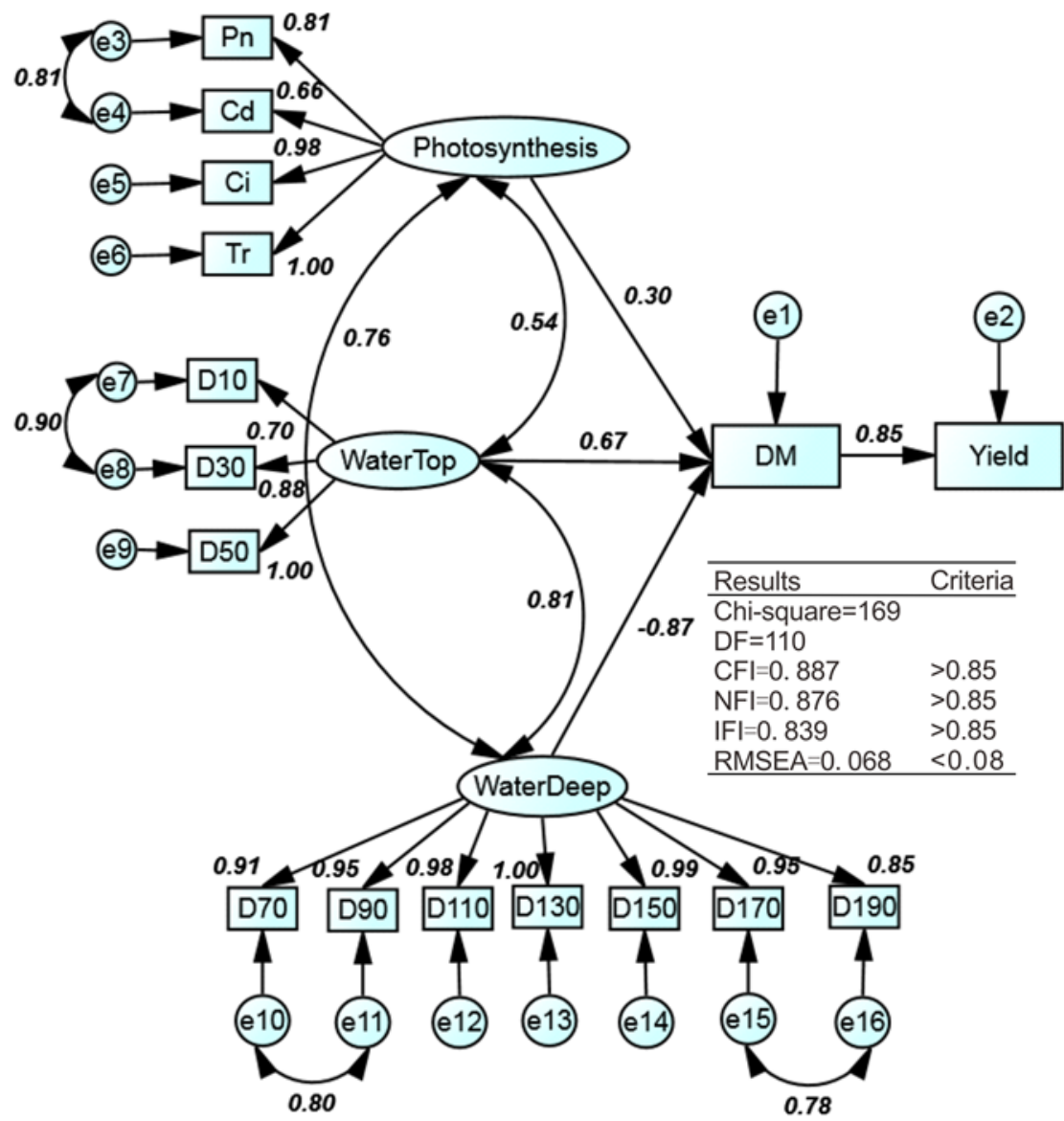

Figure 6. Final path model and fit indices for structural equation modeling for the factors influencing dry matter (DM) and yields of maize. Path coefficients are standardized model estimates. Measured variables: Pn, photosynthetic rate $\left(\mu \mathrm{mol} \mathrm{CO} \mathrm{CO}^{-2} \mathrm{~s}^{-1}\right)$; $\mathrm{Tr}$, transpiration rate $\left(\mathrm{mmol} \mathrm{H} \mathrm{O} \mathrm{m}^{-2} \mathrm{~s}^{-1}\right), \mathrm{Cd}$, stomatal conductance $\left(\mathrm{mol} \mathrm{H} \mathrm{O} \mathrm{m}^{-2} \mathrm{~s}^{-1}\right)$, and $\mathrm{Ci}$, intercellular $\mathrm{CO}_{2}$ concentration $\left(\mu \mathrm{mol} \mathrm{CO} \mathrm{mol}^{-1}\right.$ air), and D10-D200, soil water storage (SWS) at different soil depths of 10-200 cm; latent variables: Photosynthesis, watertop (top-layer SWS), and waterdeep (deep-layer SWS). DF: Degree of freedom; CFI: Comparative fit index; NFI: Normed fit index; IFI: Incremental fit index. RMSEA: Root mean square error of approximation.

\section{Discussion}

\subsection{Soil Moisture Conservation of Ridge and Furrow Planting with Manure Amendment}

Ridge and furrow maize planting with plastic mulching is a popular cropping pattern in semi-arid areas of Loess Plateau due to its effectiveness in rainwater collecting [3]. However, the rapid-extension of this cropping pattern had led to over-consumption of soil water storage (SWS) in the soil reservoir [26]. In semi-arid rain-fed areas, it was reported that ridge and furrow planted maize consumed a total SWS of $320 \mathrm{~mm}$ during growing seasons, accelerating soil water depletion below $100 \mathrm{~cm}$ soil depth, especially when it was incorporated with a large amount of chemical fertilizers [27]. In this study, RFC was shown to increase $\mathrm{ET}_{\mathrm{c}}$ by $8 \%$ and decrease $\mathrm{SWS}$ by $5 \%$ at harvest, compared to CK. However, RFM significantly conserved 10\%-17\% more SWS in 0-200 cm depth than RFC and CK did. Soil moisture conservation effect of RFM was more significant in wet year $(425 \mathrm{~mm}$ ) of 2018. In 2018, SWS of RFM was close to field capacity in the $60-120 \mathrm{~cm}$ layer at VT stage, and conserved $16 \%$ more SWS than CK did (346 mm vs. $298 \mathrm{~mm}$ ) at R3 stage in the 0-200 cm layer, and 14\% more at maturity. This was probably due to a reduction in surface runoff and soil evaporation, and an increase in rainwater infiltration due to ridge and furrow planting [28]. However, during the normal year of 2017, SWS of 
RFC and CK was close to wilting point in the $0-120 \mathrm{~cm}$ layer at VT stage, in the $40-200 \mathrm{~cm}$ layer at R3 stage, and in the 80-200 cm layer at R6 stage, indicating an over-consumption of SWS by RFC and CK. Except R3 stage, SWS of RFM was higher than wilting point in the $0-200 \mathrm{~cm}$ soil layer, alleviating water stress in maize growing season of 2017, consistent with previous studies conducted at the similar climates [3]. Manure amendment has been an effective way to optimize soil moisture use and improve soil water conservation [29]. The optimal effect of integrated use of manure amendment and ridge and furrow planting was obvious in the present study. Our results showed that DM and yields were positively correlated to SWS in the 0-60 cm layer. As desired, RFM increased SWS in the 0-60 cm layer by $21 \%, 24 \%$, and $12 \%$ at VT, R3, and R6 stages of 2017 , and by $14 \%, 12 \%$, and $6 \%$ in 2018 , respectively, compared to CK. This explained why RFM obtained the greatest yields through optimizing soil water use in top layers. In the wet year, RFR also had similar SWS to RFM; while in the normal year, RFR showed no significant effect on improving SWS as RFM did. This explained why the grain yield of RFR was lower in 2017 than in 2018. The significant advantage of RFM in soil moisture retention may be attributed to the improvement in soil properties before and after manure amendment $[30,31]$. In this study, contents of organic matter, total $\mathrm{N}$, and total $\mathrm{P}$ were increased by $16 \%\left(10.9 \mathrm{~g} \mathrm{~kg}^{-1} \mathrm{vs}\right.$. $\left.12.7 \mathrm{~g} \mathrm{~kg}^{-1}\right), 12 \%\left(1.06 \mathrm{~g} \mathrm{~kg}^{-1}\right.$ vs. $\left.1.19 \mathrm{~g} \mathrm{~kg}^{-1}\right)$, and $10 \%\left(1.09 \mathrm{~g} \mathrm{~kg}^{-1}\right.$ vs. $\left.1.20 \mathrm{~g} \mathrm{~kg}^{-1}\right)$, respectively, after the two years' incorporation of sheep manure. Similar increase in SOC, N, and P availability by sheep manure amendments was also reported in eastern Himalayas, India [32].

\subsection{Yields Boosting Effect of Ridge and Furrow Planting with Manure Amendment}

Both manure amendment and ridge and furrow planting are important strategies to improve crop productivity and guarantee food security. However, overuse of animal manure may bring about $\mathrm{N}$ leaching losses. In UK, the maximum input of cattle manure was recommended at $1.7 \mathrm{tha}^{-1} \mathrm{yr}^{-1}$ [13], which was much lower than that applied in China. In subtropical China, the threshold for long-term application of pig manure from an environmental safety perspective would be $3.6 \mathrm{t} \mathrm{ha}^{-1}$ [33]. However, in Valladolid, Spain, the highest yields were attained at an application rate of $9.5 \mathrm{tha}^{-1}$ for swine manure, much higher than the rate $\left(6 \mathrm{tha}^{-1}\right)$ used in the study [11]. Also, there were studies showing that pure manure application resulted in lower $\mathrm{N}$ availability in the early stages of crop development as it had a lower speed of nutrient release than mineral NPK did. That explained why sheep manure should be applied at a relatively lower rate and be blended with chemical $\mathrm{N}$ fertilizers in the experiment [30]. Furthermore, RFM was shown to increase SWS by $14 \%$ at harvest, improve the contents of SOM, total $\mathrm{N}$, and $\mathrm{P}$ by $10 \%-16 \%$, which were mainly due to the fact that manure can increase the contents of humic substance, and retain moisture up to $70 \%-80 \%$ of its weights, thus providing favorable soil moisture condition and suitable root zones for maize plants [34].

With regard to yields, the greatest maize yields were attained with sheep manure applied at $6 \mathrm{tha}^{-1}$ combined with $\mathrm{N}$ fertilizers at the rates of $112 \mathrm{~kg} \mathrm{ha}^{-1}$, which was in line with some studies conducted in India [14], Spain [35], and Ethiopia [16]. The yields boosting effects of the combination treatments were probably attributed to enhanced microbial activity, and soil aggregation, supplying more ammonium in soils than pure manure or mineral NPK fertilizer applied fields [36,37]. Furthermore, a reciprocal relationship was observed between the bacterial counts $\left(r^{2}=0.71, p<0.01\right)$ and SOC contents [38]. It has been reported that higher bacterial population in manure-amended soils increased the decomposition rates of manure, generating a large quantity of soil binding bioagents, which in turn benefited in soil aggregation [39].

In this study, the total NPK input remained similar among all treatments according to their percentage composition of NPK. The aim was to compare the effects of different fertilizer types at the same nutrient level. We chose a traditional fertilization method and a common flat planting pattern, which were widely adopted by local farmers, to make sure the results were more practical. Because manure and control-released fertilizer can gradually release soil nutrients even at later stages of crops, it induced higher contents of dissolved organic carbon and nitrogen than CK and RFC did, thus promoting nutrient availability [40]. The continuing supplies of available NPK by manure significantly 
enhanced photosynthetic rates, thereby resulting in the crops photosynthetic potential and the net assimilation rate also being increased, offering a substantial basis for yield formation [41].

In this study, the effects of RFM on soil water conservation had significant positive correlation with photosynthetic rates, stomatal conductance, and transpiration rates, as was manifested by the SEM analysis in Figure 6. While drought stress induced by RFC and CK might lead to the closure of stomata [42], giving rise to lower transpiration rates, as compared with RFM and RFR, eventually resulting in lower grain yield and WUE. This conclusion can be explained by the significant positive correlations among SWS at top layers, photosynthetic parameters, and grain yields using SEM analysis. RFM had relatively higher photosynthetic rates of maize than RFC and CK did. In the normal year of 2017, drought stress made RFR release less soluble nutrients in soils, producing more root-sourced signal (ABA), leading to stomatal restrictions and lowering photosynthetic rates of leaves [43]. However, in the wet year of 2018, the conducive effects of RFR on photosynthesis and yields were more noticeable, indicating that benefits of control-released fertilizer were dependent upon water availability in soils. Lower photosynthesis under RFC and CK was probably attributed to its reduced physical activity in leaves induced by drought stress [44]. Generally, in normal and wet years, RFM was the most favorable approach to meet the dual goal of conserving soil water and improving grain yields in rain-fed areas of northwest China.

\subsection{Advantage of Structural Equation Modeling}

In this study, structural equation model (SEM) allows us to assess the direct effects on DM and grain yields, and correlations among latent variables. Our results showed that photosynthetic parameters and top-layer SWS had positive beneficial effects in both seasons, whereas SWS had greater effects than photosynthesis did, indicating that top-layer SWS should take a higher priority over photosynthesis in terms of boosting grain yield. The negative effects brought by deep-layer SWS on yield demonstrated that high SWS in deep layers caused by a plenty of rainfall might create anaerobic conditions, which are harmful for root respiration [45]. Because the experimental years were normal in 2017, but wet in 2018, the negative effects may not exist in dry years due to drought stress, which needs further studies to prove. Greater contribution of top-layer SWS to grain yields probably indicated that maize roots mainly distributed in the $0-60 \mathrm{~cm}$ layer in the experiment. A study conducted in the North China Plain indicated that $80 \%$ roots of summer maize distributed in the 0-60 cm depth, which was consistent with the inference of this study [46]. However, effective rainwater harvest in deep soils due to abundant precipitation negatively affected yields of maize. The SEM results suggested that photosynthesis and top-layer SWS had positive effects on DM and yields, in which SWS should be a dominant factor for maize growth and development. However, it is worth noting that SWS in top and deep layers had contrary effects on DM and yield formation.

In detail, SEM analysis showed that SWS affected maize yield primarily via direct effects of top-layer SWS rather than via affecting deep-layer SWS and photosynthetic rates. RFC and CK usually induced water stress to plants, which is known to cause higher stomatal resistance in maize leaves as a way to reduce $\mathrm{ET}_{\mathrm{c}}$, minimizing $\mathrm{CO}_{2}$ diffusion into the sub-stomatal cavities, and giving rise to limited photosynthetic rates [44], as is shown in the present study. A latest study showed that there existed a negative correlation between $\mathrm{ET}_{\mathrm{C}}$ and SWS in deep layers, and the phenomenon might be attributable to the gravitational forces acting on it [47]. Gravitational forces on soil water movement were greater than the driving forces generated by root absorption in deep soil layers, reducing the probability of deep-layer SWS to participate into plant photosynthesis, negatively affecting crop yields $[48,49]$.

\section{Conclusions}

This study examined the overall impact of planting patterns and manure amendment as means to improve grain yields of maize in Loess Plateau, northwest China. The aim was to assess the effects of multiple management strategies on soil moisture across $0-200 \mathrm{~cm}$ soil layers, photosynthetic factors, and dry matter accumulation through field experiments. This work highlights the importance of 
manure amendment on soil moisture conservation and dry matter accumulation, and proves that the combined management strategies have the greatest effect on yield boosting. Applying sheep manure at $6 \mathrm{t} \mathrm{ha}^{-1}$ can save $50 \%$ of $\mathrm{N}$ fertilization and produces the greatest yields. Also, the combined strategy conserved $10 \%$ more SWS and reduced $8 \% \mathrm{ET}_{\mathrm{c}}$ than CK did. The SEM analysis demonstrated that SWS is a dominant factor determining maize yields. Top-layer SWS had positive effects on yields while deep-layer SWS showed negative effects. The negative correlation may be attributable to the gravitational forces acting on it. The contribution of photosynthesis to dry matter and yield of maize is low $(7 \%-9 \%)$. Our results validate the hypothesis that incorporation of manure into ridge and furrow planting system improved soil water availability, increased leaf photosynthesis, and boosted yields. Our research also helps farmers focus on the key factors in boosting grain yields, thereby allowing them to pay much attention to SWS in top layers $(0-60 \mathrm{~cm})$ in semi-arid areas of northwest China.

Supplementary Materials: The following are available online at http://www.mdpi.com/2073-4395/9/12/865/s1, Table S1: Eigenvalues extracted from correlation matrix of relevant photosynthetic parameters and soil water content data and their principal components obtained through principal component analysis (PCA). Table S2: Rotated components matrix based on principal component procedure using Kaiser's standard orthogonal rotation after the six iterations.

Author Contributions: Conceptualization, A.Q. and Y.F.; methodology, D.N.; software, Z.L.; validation, B.Z.; formal analysis, J.X.; investigation, B.Y.; resources, A.D.; data curation, B.Y.; writing-original draft preparation, A.Q.; writing一review and editing, Y.F.

Funding: This research was funded by the National Key Research and Development Program (2017YFD0301102), the Gansu Provincial Key Research and Development Program (18YF1WA092), the China Agriculture Research System (CARS-02), the Open Fund of Farmland Irrigation Research Institute, CAAS (FIRI2018-08-02), and the Agricultural Science and Technology Innovation Program (2017GAAS27). And the article processing charges (APC) was funded by the National Key Research and Development Program (2017YFD0301102).

Acknowledgments: The authors sincerely thank the two anonymous reviewers for their valuable comments and suggestions that helped improve the quality of this manuscript.

Conflicts of Interest: The authors declare no conflict of interest.

\section{References}

1. Ren, X.; Chen, X.; Jia, Z. Effect of rainfall collecting with ridge and furrow on soil moisture and root growth of corn in semiarid northwest China. J. Agron. Crop Sci. 2010, 196, 109-122. [CrossRef]

2. Ali, S.; Jan, A.; Zhang, P.; Khan, M.N.; Cai, T.; Wei, T.; Ren, X.; Jia, Q.; Han, Q.; Jia, Z. Effects of ridge-covering mulches on soil water storage and maize production under simulated rainfall in semiarid regions of China. Agric. Water Manag. 2016, 178, 1-11. [CrossRef]

3. Wang, H.; Zhang, X.; Yu, X.; Hou, H.; Fang, Y.; Ma, Y. Maize-faba bean rotation under double ridge and furrows with plastic mulching alleviates soil water depletion. Agric. Water Manag. 2018, 207, 59-66. [CrossRef]

4. Li, R.; Hou, X.; Jia, Z.; Han, Q.; Ren, X.; Yang, B. Effects on soil temperature, moisture, and maize yield of cultivation with ridge and furrow mulching in the rainfed area of the Loess Plateau, China. Agric. Water Manag. 2013, 116, 101-109. [CrossRef]

5. Gan, Y.T.; Siddique, K.H.M.; Turner, N.C.; Li, X.G.; Niu, J.; Yang, C.; Liu, L. Ridge-furrow mulching systems-An innovative technique for boosting crop productivity in semiarid rain-fed environments-Chapter seven. Adv. Agron. 2013, 118, 429-476.

6. Qin, S.; Zhang, J.; Dai, H.; Wang, D.; Li, D. Effect of ridge-furrow and plastic-mulching planting patterns on yield formation and water movement of potato in a semi-arid area. Agric. Water Manag. 2014, 131, 87-94. [CrossRef]

7. Wang, T.; Wei, L.; Wang, H.; Ma, S.; Ma, B. Responses of rainwater conservation, precipitation-use efficiency and grain yield of summer maize to a furrow-planting and straw-mulching system in northern China. Field Crops Res. 2011, 124, 223-230. [CrossRef]

8. Zhao, H.; Wang, R.; Ma, B.; Xiong, Y.; Qiang, S.; Wang, C.; Liu, C.; Li, F. Ridge-furrow with full plastic film mulching improves water use efficiency and tuber yields of potato in a semiarid rainfed ecosystem. Field Crops Res. 2014, 161, 137-148. [CrossRef] 
9. Zeng, J.; Liu, X.; Song, L.; Lin, X.; Zhang, H.; Shen, C.; Chu, H. Nitrogen fertilization directly affects soil bacterial diversity and indirectly affects bacterial community composition. Soil Biol. Biochem. 2016, 92, 41-49. [CrossRef]

10. Iqbal, S.; Arif, M.; Thierfelder, C.; Yasmeen, T.; Li, T. Reducing nitrogen losses and increasing maize productivity in organic manures-amended soils by increasing the ridge to furrow proportion. Exp. Agric. 2019, 55, 428-442. [CrossRef]

11. Sánchez-Báscones, M.; Antolín-Rodríguez, J.M.; Bravo-Sánchez, C.T.; Martín-Gil, J.; Martín-Ramos, P. Dried pig manure from a cogeneration plant as a fertilizer for nitrate vulnerable zones. Agronomy 2019, 9, 46. [CrossRef]

12. Amusan, A.O.; Adetunji, M.T.; Azeez, J.O.; Bodunde, J.G. Effect of the integrated use of legume residue, poultry manure and inorganic fertilizers on maize yield, nutrient uptake and soil properties. Nutr. Cycl. Agroecosyst. 2011, 90, 321-330. [CrossRef]

13. Tétard-Jones, C.; Edwards, M.G.; Rempelos, L.; Gatehouse, A.M.; Eyre, M.; Wilcockson, S.J.; Leifert, C. Effects of previous crop management, fertilization regime and water supply on potato tuber proteome and yield. Agronomy 2013, 3, 59-85. [CrossRef]

14. Gosal, S.K.; Gill, G.K.; Sharma, S.; Walia, S.S. Soil nutrient status and yield of rice as affected by long-term integrated use of organic and inorganic fertilizers. J. Plant Nutr. 2018, 41, 539-544. [CrossRef]

15. Cisse, A.; Arshad, A.; Wang, X.; Yattara, F.; Hu, Y. Contrasting Impacts of long-term application of biofertilizers and organic manure on grain yield of winter wheat in North China Plain. Agronomy 2019, 9, 312. [CrossRef]

16. Bayu, W.; Rethman, N.F.G.; Hammes, P.S.; Alemu, G. Effects of farmyard manure and inorganic fertilizers on sorghum growth, yield, and nitrogen use in a semi-arid area of Ethiopia. J. Plant Nutr. 2006, 29, 391-407. [CrossRef]

17. Adediran, J.A.; Taiwo, L.B.; Akande, M.O.; Sobulo, R.A.; Idowu, O.J. Application of organic and inorganic fertilizer for sustainable maize and cowpea yields in Nigeria. J. Plant Nutr. 2005, 27, 1163-1181. [CrossRef]

18. Alpha, J.; Chen, J.; Zhang, G. Effect of nitrogen fertilizer forms on growth, photosynthesis, and yield of rice under Cadmium stress. J. Plant Nutr. 2009, 32, 306-317. [CrossRef]

19. Li, Y.; Song, H.; Zhou, L.; Xu, Z.; Zhou, G. Vertical distributions of chlorophyll and nitrogen and their associations with photosynthesis under drought and rewatering regimes in a maize field. Agric. For. Meteorol. 2019, 272, 40-54. [CrossRef]

20. Schiavon, M.; Ertani, A.; Francioso, O.; Nardi, S. Manure fertilization gives high-quality earthworm coprolites with positive effects on plant growth and N metabolism. Agronomy 2019, 9, 659. [CrossRef]

21. Arhonditsis, G.B.; Stow, C.A.; Steinberg, L.J.; Kenney, M.A.; Lathrop, R.C.; McBride, S.J.; Reckhow, K.H. Exploring ecological patterns with structural equation modeling and Bayesian analysis. Ecol. Model. 2006, 192, 385-409. [CrossRef]

22. Pollman, C.D. Mercury cycling in aquatic ecosystems and trophic state-related variables-Implications from structural equation modeling. Sci. Total Environ. 2014, 499, 62-73. [CrossRef] [PubMed]

23. Chinese Soil Taxonomy Cooperative Research Group. Chinese Soil Taxonomy (Revised Proposal); Institute of Soil Science/Chinese Agricultural Science and Technology Press, Academic Sinica: Beijing, China, 1995; pp. $42-59$.

24. Gao, X.; Li, C.; Zhang, M.; Wang, R.; Chen, B. Controlled release urea improved the nitrogen use efficiency, yield and quality of potato (Solanum tuberosum L.) on silt loamy soil. Field Crops Res. 2015, 181, 60-68. [CrossRef]

25. Stevens, R.D.; Tello, J.S. A latitudinal gradient in dimensionality of biodiversity. Ecography 2018, 41, $2016-2026$. [CrossRef]

26. Zhou, L.; Jin, S.; Liu, C.; Xiong, Y.; Si, J.; Li, X.; Gan, Y.; Li, F. Ridge-furrow and plastic-mulching tillage enhances maize-soil interactions: Opportunities and challenges in a semiarid agroecosystem. Field Crops Res. 2012, 126, 181-188. [CrossRef]

27. Ren, X.; Zhang, P.; Chen, X.; Guo, J.; Jia, Z. Effect of different mulches under rainfall concentration system on corn production in the semi-arid areas of the Loess Plateau. Sci. Rep. 2016, 6, 19019. [CrossRef] 
28. Zhou, L.; Li, F.; Jin, S.; Song, Y. How two ridges and the furrow mulched with plastic film affect soil water, soil temperature and yield of maize on the semiarid Loess Plateau of China. Field Crops Res. 2009, 113, 41-47. [CrossRef]

29. Hengsdijk, H.; Meijerinkb, G.W.; Mosuguc, M.E. Modeling the effect of three soil and water conservation practices in Tigray, Ethiopia. Agric. Ecosyst. Environ. 2005, 105, 29-40. [CrossRef]

30. Saha, S.; Prakash, V.; Kundu, S.; Kumar, N.; Mina, B.L. Soil enzymatic activity as affected by long term application of farm yard manure and mineral fertilizer under a rainfed soybean-wheat system in $\mathrm{N}-\mathrm{W}$ Himalaya. Eur. J. Soil Biol. 2008, 44, 309-315. [CrossRef]

31. Boitt, G.; Simpson, Z.P.; Tian, J.; Black, A.; Wakelin, S.A.; Condron, L.M. Plant biomass management impacts on short-term soil phosphorus dynamics in a temperate grassland. Biol. Fertil. Soils 2018, 54, 397-409. [CrossRef]

32. Das, A.; Patel, D.; Kumar, M.; Ramkrushna, G.; Mukherjee, A.; Layek, J.; Ngachan, S.; Buragohain, J. Impact of seven years of organic farming on soil and produce quality and crop yields in eastern Himalayas, India. Agric. Ecosyst. Environ. 2017, 236, 142-153. [CrossRef]

33. Long, G.; Sun, B. Nitrogen leaching under corn cultivation stabilized after four years application of pig manure to red soil in subtropical China. Agric. Ecosyst. Environ. 2012, 146, 73-80. [CrossRef]

34. Maji, D.; Misra, P.; Singh, S.; Kalra, A. Humic acid rich vermicompost promotes plant growth by improving microbial community structure of soil as well as root nodulation and mycorrhizal colonization in the roots of Pisum sativum. Appl. Soil Ecol. 2017, 110, 97-108. [CrossRef]

35. Melero-Vara, J.M.; López-Herrera, C.J.; Prados-Ligero, A.M.; Vela-Delgado, M.D.; Navas-Becerra, J.A.; Basallote-Ureba, M.J. Effects of soil amendment with poultry manure on carnation Fusarium wilt in greenhouses in southwest Spain. Crop Prot. 2011, 30, 970-976. [CrossRef]

36. Dambreville, C.; Hallet, S.; Nguyen, C.; Morvan, T.; Germon, J.C.; Philippot, L. Structure and activity of the denitrifying community in a maize-cropped field fertilized with composted pig manure or ammonium nitrate. FEMS Microbiol. Ecol. 2006, 56, 119-131. [CrossRef]

37. Iqbal, A.; He, L.; Khan, A.; Wei, S.; Akhtar, K.; Ali, I.; Ullah, S.; Munsif, F.; Zhao, Q.; Jiang, L. Organic manure coupled with inorganic fertilizer: An approach for the sustainable production of rice by improving soil properties and nitrogen use efficiency. Agronomy 2019, 9, 651. [CrossRef]

38. Dubey, R.; Dubey, P.; Abhilash, P. Sustainable soil amendments for improving the soil quality, yield and nutrient content of Brassica juncea (L.) grown in different agroecological zones of eastern Uttar Pradesh, India. Soil Tillage Res. 2019, 195, 104418. [CrossRef]

39. Wright, S.; Upadhyaya, A. A survey of soils for aggregate stability and glomalin, a glycoprotein produced by hyphae of arbuscular mycorrhizal fungi. Plant Soil 1998, 198, 97-107. [CrossRef]

40. Xin, X.; Qin, S.; Zhang, J.; Zhu, A.; Yang, W.; Zhang, X. Yield, phosphorus use efficiency and balance response to substituting long-term chemical fertilizer use with organic manure in a wheat-maize system. Field Crop. Res. 2017, 208, 27-33. [CrossRef]

41. Sun, Y.; Mi, W.; Su, L.; Shan, Y.; Wu, L. Controlled-release fertilizer enhances rice grain yield and $\mathrm{N}$ recovery efficiency in continuous non-flooding plastic film mulching cultivation system. Field Crop. Res. 2019, 231, 122-129. [CrossRef]

42. Wang, X.; Ren, Y.; Zhang, S.; Chen, Y.; Wang, N. Applications of organic manure increased maize (Zea mays L.) yield and water productivity in a semi-arid region. Agric. Water Manag. 2017, 187, 88-98. [CrossRef]

43. Daszkowska-Golec, A.; Szarejko, I. Open or close the gate-Stomata action under the control of phytohormones in drought stress conditions. Front. Plant Sci. 2013, 4, 138. [CrossRef] [PubMed]

44. Zhang, D.; Jiao, X.; Du, Q.; Song, X.; Li, J. Reducing the excessive evaporative demand improved photosynthesis capacity at low costs of irrigation via regulating water driving force and moderating plant water stress of two tomato cultivars. Agric. Water Manag. 2018, 199, 22-33. [CrossRef]

45. Raich, J.W.; Mora, G. Estimating root plus rhizosphere contributions to soil respiration in annual croplands. Soil Sci. Soc. Am. J. 2005, 69, 634-639. [CrossRef]

46. Qin, A.; Ning, D.; Liu, Z.; Sun, B.; Zhao, B.; Xiao, J.; Duan, A. Insentek sensor: An alternative to estimate daily crop evapotranspiration for maize plants. Water 2019, 11, 25. [CrossRef]

47. Qin, A.; Ning, D.; Liu, Z.; Sun, B.; Zhao, B.; Xiao, J.; Duan, A. Structural equation modeling of soil moisture effects on evapotranspiration of maize in the North China Plain. Natl. Acad. Sci. Lett. 2019, 42, 1-6. [CrossRef] 
48. Yao, J.; Cheng, J.; Sun, L.; Zhang, X.; Zhang, H. Effect of antecedent soil water on preferential flow in four soybean plots in southwestern China. Soil Sci. 2017, 182, 83-93. [CrossRef]

49. Garrigues, S.; Boone, A.; Decharme, B.; Olioso, A.; Albergel, C.; Calvet, J.; Moulin, S.; Buis, S.; Martin, E. Impacts of the soil water transfer parameterization on the simulation of evapotranspiration over a 14-year Mediterranean crop succession. J. Hydrometeorol. 2018, 19, 3-25. [CrossRef]

(C) 2019 by the authors. Licensee MDPI, Basel, Switzerland. This article is an open access article distributed under the terms and conditions of the Creative Commons Attribution (CC BY) license (http://creativecommons.org/licenses/by/4.0/). 